\title{
Dimethylsulfide emissions over the multi-year ice of the western Weddell Sea
}

\author{
H. J. Zemmelink, ${ }^{1,2,3}$ J. W. H. Dacey, ${ }^{3}$ L. Houghton, ${ }^{3}$ E. J. Hintsa, ${ }^{3}$ and P. S. Liss ${ }^{1}$ \\ Received 28 August 2007; revised 6 February 2008; accepted 13 February 2008; published 20 March 2008.
}

[1] This study, conducted in December 2004, is the first to present observations of DMS in a snow pack covering the multi-year sea ice of the western Weddell Sea. The snow layer is important because it is the interface through which DMS needs to be transported in order to be emitted directly from the ice to the overlying atmosphere. High concentrations of DMS, up to $6000 \mathrm{nmol} \mathrm{m}^{-3}$, were found during the first weeks of December but concentrations sharply decline as late spring-early summer progresses. This implies that DMS contained in sea ice is efficiently vented through the snow into the atmosphere. Indeed, field measurements by relaxed eddy accumulation indicate an average release of $11 \mu \mathrm{mol}$ DMS m${ }^{-2} \mathrm{~d}^{-1}$ from the ice and snow throughout December. Citation: Zemmelink, H. J., J. W. H. Dacey, L. Houghton, E. J. Hintsa, and P. S. Liss (2008), Dimethylsulfide emissions over the multi-year ice of the western Weddell Sea, Geophys. Res. Lett., 35, L06603, doi:10.1029/ 2007 GL031847.

\section{Introduction}

[2] In sea ice lie habitats that appear to be highly productive during spring and summer, and sea ice communities are thought to make a major contribution to global carbon [Semiletov et al., 2004; Zemmelink et al., 2006] and sulfur cycling [Trevena et al., 2003; Zemmelink et al., 2005]. Via melting, inorganic and organic particulates (including sea ice algae) contained within the ice are released to the upper water column. Commonly associated with the retreating sea ice edge are phytoplankton blooms that account for a considerable portion of polar productivity [e.g., Arrigo, 1998].

[3] Associated with these blooms of microalgae are some of the world's highest concentrations of algal-derived dimethylsulfoniopropionate (DMSP) and its gaseous degradation product dimethylsulfide (DMS) [e.g., Gabric et al., 2005]. These sulfur compounds are of great interest to because they are part of a biogeochemical system that transfers sulfur from the oceans to the atmosphere, via DMS. In the atmosphere, DMS is oxidized to methanesulfonic acid (MSA) and sulfate particles, which can act as cloud condensation nuclei [Gondwe et al., 2003]. This input of sulfur affects atmospheric chemistry, cloud microphysics and direct scattering of solar radiation [Gabric et al., 2003,

\footnotetext{
${ }^{1}$ School of Environmental Sciences, University of East Anglia, Norwich, U.K

${ }^{2}$ Royal Netherlands Institute for Sea Research, Den Burg, Netherlands. U.S.A

${ }^{3}$ Woods Hole Oceanographic Institution, Woods Hole, Massachusetts,
}

Copyright 2008 by the American Geophysical Union. 0094-8276/08/2007GL031847\$05.00
2004]. The latter two processes have potentially strong impacts on regional and global climate dynamics [Shaw, 1985; Charlson et al., 1987].

[4] Although the release and the transformation processes affecting the fate of sea ice DMSP and DMS during sea ice melting have been extensively studied in recent years [Curran and Jones, 2000; Gabric et al., 2005; Trevena and Jones, 2006], there is still limited knowledge of the transfer of DMS from the ice to the atmosphere.

[5] The potentially significant flux of DMS from surface waters to the atmosphere related to sea ice melting has already been pointed out by several authors. Curran and Jones [2000] were among the first to suggest that DMS was being released from melting sea ice in open water leads, and that elevated levels of atmospheric DMS above the sea ice could reflect degassing of DMS from the sea ice. This is supported by later studies. Zemmelink et al. [2005] suggested that the release of DMS from open water leads could produce significant spikes of DMS flux towards the overlying atmosphere. Recently, Trevena and Jones [2006] also suggested that the release of DMSP and DMS during sea ice melting may result in "hot spots of seawater DMS with concentrations of the order of $100 \mathrm{nM}$, which could contribute significantly to the atmospheric DMS load. However, in light of the growing evidence that $\mathrm{CO}_{2}$ fluxes occur at the sea ice - air interface [Semiletov et al., 2004; Zemmelink et al., 2006], it could be argued that sea ice becomes permeable and allows direct transfer of gases from the ice, through the overlying snow layer, to the atmosphere. Considering the high amounts of DMS that can be found in sea ice (up to $75 \mathrm{nM}$ ) [Trevena and Jones, 2006], the direct DMS flux to the atmosphere from the sea ice could be significant. Gabric et al. [2005] hypothesize that spring early summer pulses of DMS emanating from melting sea ice contributes to the widespread aerosol loading which precedes the main summer chlorophyll and DMS peak in surface waters. Observations suggest that there are at least two sources of DMS to the atmosphere in this region, one linked to melting sea ice and one linked to the phytoplankton bloom phase [Gabric et al., 2005]. From these studies it is hypothesized that the emission of DMS from sea ice might not be confined to melting processes and plankton blooms in open waters. In this study we present direct field measurements of the DMS flux over the perennial ice zone of the western Weddell Sea.

\section{Materials and Methods}

[6] This study was performed during the 2004 Ice Station Polarstern (ISPOL) cruise, in the western Weddell Sea through November-December (the late spring - early summer season). 
[7] The vertical flux of DMS and $\mathrm{CO}_{2}$ was measured at a height of $2.75 \mathrm{~m}$ using the relaxed eddy accumulation (REA) technique. The REA system was an integrated part of an eddy correlation (EC) system (Applied Technologies, Inc) that was simultaneously used for the measurement of $\mathrm{CO}_{2}$ fluxes over the ice [Zemmelink et al., 2006]. The EC/ REA system was battery powered; the battery pack and computers were placed in a shelter at a distance of $20 \mathrm{~m}$ from the meteorological tower.

[8] With REA, discrete air samples are taken for determination of fluxes [Zemmelink et al., 2004]. Samples are collected in two reservoirs depending on the sign of the vertical wind velocity. The flux $(\mathrm{F})$ is subsequently calculated from the product of the eddy accumulation coefficient $\beta(\beta \approx 0.6)$, the standard deviation of the vertical wind speed $\left(\sigma_{\mathrm{w}}\right)$, and the mean concentration difference of the gas of interest between the samples collected during upward and downward wind $(\Delta C)$. In a simplified formula the flux is calculated according to: $\mathrm{F}=\beta \sigma_{\mathrm{w}} \Delta \mathrm{C}$ [see also Zemmelink et al., 2004]. Hence, REA is an indirect method for measuring gas fluxes. In contrast EC is considered to be the most direct method for measuring gas fluxes [Fairall et al., 2000], since it derives the flux from the covariance of gas concentrations and vertical wind velocities.

[9] Air was sampled in the vicinity of a sonic anemometer at a flow rate of $200 \mathrm{ml} \mathrm{min}^{-1}$ for 1 hour, and collected in Tedlar bags. Subsequently, bags were brought back to the ship's laboratory and analyzed for DMS using a gas chromatograph equipped with a Sulfur Chemiluminescence Detector (Sievers). $\mathrm{CO}_{2}$ in the collection reservoirs was analyzed by a closed path infrared $\mathrm{CO}_{2} / \mathrm{H}_{2} \mathrm{O}$ analyzer ( $\mathrm{Li}$ 7000, Li-COR, USA). Fluxes are indicated according micrometeorological convention: positive when directed upward.

[10] The integrated EC/REA system allows testing the accuracy of REA by comparison of two simultaneously conducted measurements of $\mathrm{CO}_{2}$ exchange. Using $\mathrm{CO}_{2}$ flux data derived from EC measurements, a linear regression was calculated for the observations of $\mathrm{CO}_{2}$ flux measured by REA against those measured by EC (Figure 1). Good agreement was found between the two techniques, with $\mathrm{F}_{\mathrm{REA}}=0.84 \mathrm{~F}_{\mathrm{EC}}-0.1 \mathrm{gm}^{-2} \mathrm{~d}^{-1}\left(\mathrm{R}^{2}=0.68\right)$. The uncertainty of the EC measurements was 10-30\% [Zemmelink et al., 2006], where the uncertainty of REA methods is typically higher.

[11] DMS concentrations in the snow were determined near the base of the meteorological tower. Two liters of air from a series of inlets at different depths in the snow were sampled through thick-walled Teflon tubing to vacuum pulled airtight boxes (SKC, Inc.), into which Tedlar bags were placed for sample accumulation [Hintsa et al., 2004]. Subsequently, the bags were brought back to the ship's laboratory and analyzed for DMS.

[12] Sea ice and snow conditions have been extensively discussed by Zemmelink et al. [2006]. The most relevant findings were that two types of snow could be distinguished: snow that covered slush and snow that covered solid ice. Sudden changes in snow conditions occurred toward the end of December, when melting of snow and surface flooding was observed and slush and melt ponds formed at the surface of the snow, in addition to an increase in slush between the ice and overlying snow. Refreezing of water in the snow resulted in the formation of granulated snow and of superimposed ice.

\section{Results and Discussion}

[13] DMS concentrations in the slush varied between $<1 \mathrm{nM}$ to $92 \mathrm{nM}$ with the highest concentrations found in the biologically productive brown slush. High concentrations of DMSP (up to $11352 \mathrm{nM}$ ) were found in this slush layer; these concentrations are in the same range as previously measured by Trevena and Jones [2006]. In the snow-encapsulated air above the slush layer, high concentrations of DMS were found (Figure 2a), averaging from $2290 \mathrm{nmol} \mathrm{m}^{-3}$ (with a maximum of $6000 \mathrm{nmol} \mathrm{m}^{-3}$ ) at $0.15 \mathrm{~m}$ to $103 \mathrm{nmol} \mathrm{m}^{-3}$ at $0.45 \mathrm{~m}$ above the slush. Above solid ice (Figure $2 \mathrm{~b}$ ) concentrations averaged from $138 \mathrm{nmol} \mathrm{m}^{-3}$ at $0.15 \mathrm{~m}$ to $6.1 \mathrm{nmol}$ $\mathrm{m}^{-3}$ at $0.45 \mathrm{~m}$. Measurements show that DMS concentrations in the snow vary and drop after Day 348 (December 13). However, concentrations above slush remained high, with concentrations ranging from $350 \mathrm{nmol} \mathrm{m}^{-3}$ at $0.15 \mathrm{~m}$ from the ice to near atmospheric values of $0.5 \mathrm{nmol} \mathrm{m}^{-3}$ at the top of the snow layer. DMS concentrations above solid ice remained significant, with values of $5 \mathrm{nmol} \mathrm{m}^{-3}$ at $0.15 \mathrm{~cm}$ from the ice and near atmospheric values at the snow surface. The DMS concentration in the atmosphere during this time period remained relatively low at around 0.2 to $5 \mathrm{nmol} \mathrm{m}^{-3}$. A maximum in atmospheric DMS of $5 \mathrm{nmol} \mathrm{m}^{-3}$ was found on Day 344. Atmospheric DMS values toward the end of December remained around $0.7 \mathrm{nmol} \mathrm{m}^{-3}$. In an earlier study Curran and Jones [2000] found levels of atmospheric DMS above sea ice in the Australian sector of the Southern Ocean that ranged from an average of $1.3 \mathrm{nmol} \mathrm{m}^{-3}$ in November to $0.31 \mathrm{nmol} \mathrm{m}{ }^{-3}$ in December 1994.

[14] The DMS gradients found in the snow paralleled $\mathrm{CO}_{2}$ gradients recently published by Zemmelink et al. [2006], where $\mathrm{CO}_{2}$ became depleted near the ice/snow boundary. Increasing biological productivity of diatoms at this interface could result in a decrease of $\mathrm{CO}_{2}$ and is likely to be linked with the production of sulfur compounds [Trevena et al., 2000].

[15] The sudden decrease of DMS in the snow pack, and the lower concentrations found after Day 348, suggests that DMS is readily vented to the atmosphere. Changing snow characteristics will also affect the efficiency of DMS transport. Snow characteristics became very heterogeneous toward the end of December. Although gas transfer might become hampered due to the formation of ice lenses, coarse snow is likely to allow more exchange with the overlying atmosphere.

[16] Recent studies have shown that gas transport through snow could well be determined by turbulent air [Albert and Shultz, 2002; Takagi et al., 2005]. Also, substantial fluxes of $\mathrm{CO}_{2}$ (up to $0.8 \mathrm{~g} \mathrm{CO}_{2} \mathrm{~m}^{-2} \mathrm{~d}^{-1}$ [Zemmelink et al., 2006], and $1.7 \mathrm{~g} \mathrm{CO}_{2} \mathrm{~m}^{-2} \mathrm{~d}^{-1}$ [Semiletov et al., 2004]) measured by eddy correlation over sea ice indicate that these fluxes must be supported by an active transport mechanism. It is therefore reasonable to assume that the high concentrations of DMS in the snow pack can support significant emissions to the atmosphere, especially when the overlying snow pack is coarsely granulated, as observed during the last week of December. 


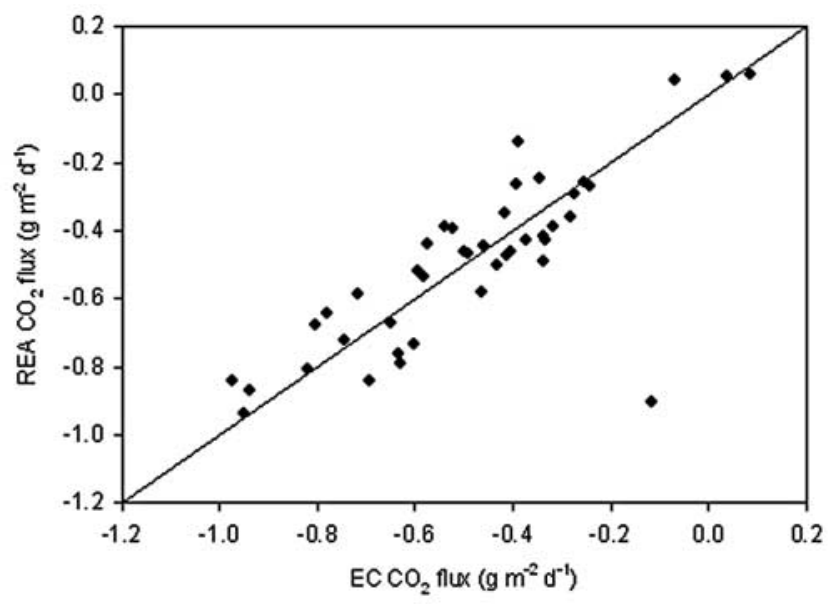

Figure 1. Comparison between the $\mathrm{CO}_{2}$ flux $\left(\mathrm{g} \mathrm{m}^{-2} \mathrm{~d}^{-1}\right)$ measured with relaxed eddy accumulation (REA) and with eddy correlation (EC) techniques based on 60-min. $\mathrm{CO}_{2}$ flux measurements carried out over sea ice. Regression: $\mathrm{REA}=0.84 \mathrm{EC}-0.1 \mathrm{~g} \mathrm{~m}^{-2} \mathrm{~d}^{-1}, \mathrm{R}^{2}=0.68$. A negative flux indicates $\mathrm{CO}_{2}$ uptake by the ice. Solid line is the 1:1 line.

[17] REA measurements of the emission of DMS showed a slow increase of fluxes over the floe over the course of December, with lower flux values $\left(<10 \mu \mathrm{mol}_{\mathrm{DMS}} \mathrm{m}^{-2} \mathrm{~d}^{-1}\right)$ mainly until Day 355, increasing toward a maximum flux of $29 \mu \mathrm{mol}_{\text {DMS }} \mathrm{m}^{-2} \mathrm{~d}^{-1}$ by the end of the month (Figure 3 ). The average emission of DMS was $11 \mu \mathrm{mol}_{\mathrm{DMS}} \mathrm{m}^{-2} \mathrm{~d}^{-1}$. The variability and sudden drop of DMS concentrations in the snow were not reflected in the flux measurements. It could be that these were local pulsed events that were not measured by the discrete sampling approach of REA. (Or that the rapid changes in snow concentrations were not spatially homogeneous, and would therefore not show up as pulses in a flux measurement over a substantial fetch area). The average flux of $11 \mu \mathrm{mol}_{\text {DMS }} \mathrm{m}^{-2} \mathrm{~d}^{-1}$ is very similar to estimates of $9.4 \mu \mathrm{mol}_{\mathrm{DMS}} \mathrm{m}^{-2} \mathrm{~d}^{-1}$ (ranging from 1.7$49 \mu \mathrm{mol}_{\text {DMS }} \mathrm{m}^{-2} \mathrm{~d}^{-1}$ ) over the seasonal ice zone of the Australian part of the Southern Ocean [Curran and Jones, 2000]. Their DMS flux estimates from the Subantarctic Zone, Antarctic Zone and Seasonal Ice Zone range from 1.7 to $49 \mu \mathrm{mol}_{\mathrm{DMS}} \mathrm{m}^{-2} \mathrm{~d}^{-1}$. It must be mentioned that the flux estimates of Curran and Jones [2000] do not include contributions from the sea ice and, moreover, are averaged over spring and summer. Our results support the thesis of Curran and Jones [2000] that large amounts of DMS emanate from melting sea ice from the Seasonal Ice Zone, which seems to be detected in the satellite record of aerosol optical depth over the sea ice in spring [Gabric et al., 2005]. Our observations as well as the previously published observations indicate that this DMS pulse to the atmosphere is fairly uniform during the transition period from late spring (November) to early summer (December). This could indicate that there are different events that contribute to the atmospheric loading of DMS: one linked to changes in snow characteristics (observed in this study), one emanating from melting sea ice, and one from biological activity in sea water [Gabric et al., 2005]. These studies emphasize the importance of sea ice for atmospheric DMS and further support the hypothesis of Gabric et al. [2005] that the loss of sea ice since 1950 would have decreased emissions of DMS in this region and consequently the levels of DMS-derived aerosols, such as atmospheric MSA.

[18] Extrapolating the flux measured by REA of $11 \mu \mathrm{mol}_{\text {DMS }} \mathrm{m}^{-2} \mathrm{~d}^{-1}$ to the multi-year ice zone in the western Weddell Sea (extending to $1.3 * 10^{6} \mathrm{~km}^{2}$ [Gloersen et al., 1992]) results in a total December flux of sulfur to the atmosphere of $15 \mathrm{Gg} \mathrm{S}$ (This includes the $0.47 \mathrm{Gg} \mathrm{S}$ flux from open water leads as estimated by Zemmelink et al. [2005]. Emission of DMS from the ice-free waters in the Antarctic region of the Southern Ocean $\left(50^{\circ} \mathrm{S}-70^{\circ} \mathrm{S}\right)$ has been estimated to range from $26-85 \mathrm{G} \mathrm{mol} \mathrm{S} \mathrm{yr}^{-1}$ [Curran and Jones, 2000; Kettle and Andreae, 2000]. The flux from the icecovered Weddell Sea would therefore amount to $1.7-5.6 \%$ of the yearly sulfur flux from the Antarctic region of the Southern Ocean. What effect this has on the radiative forcing over the Antarctic sea ice is unknown but is likely to be significant.

[19] However, it is likely that as spring and summer progress, the biological activity in the ice would increase, with ongoing production of DMSP and DMS. This implies that fluxes from the ice might continue during January and February. Hence, the total summer emissions (from December-February) of DMS from the sea ice to the atmosphere could be as high as $6-18 \%$ of the yearly emission of the Southern Ocean between $50^{\circ} \mathrm{S}-70^{\circ} \mathrm{S}$. This estimate is based on an emission of $15.5 \mathrm{Gg} \mathrm{S}$ per month;
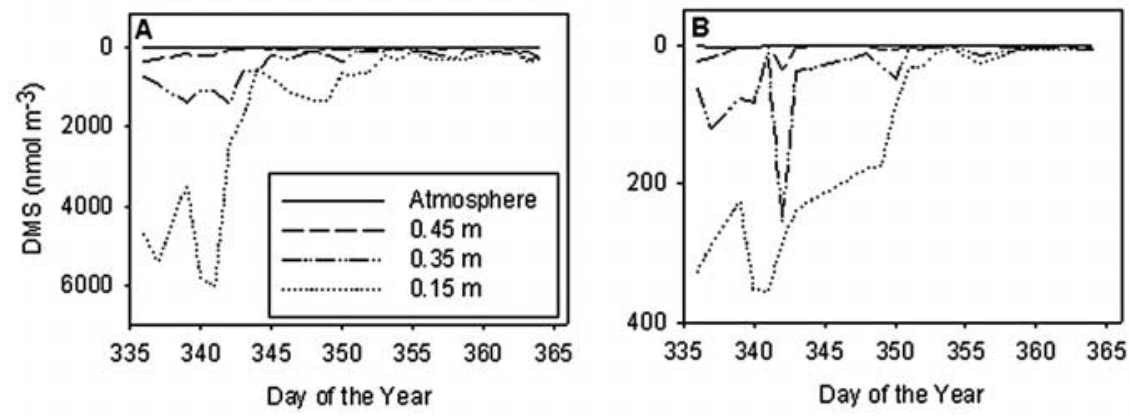

Figure 2. DMS concentrations $\left(\mathrm{nmol} \mathrm{m} \mathrm{m}^{-3}\right)$ in snow, as a function of distance from the ice surface $(0.15 \mathrm{~m}, 0.35 \mathrm{~m}$ and $0.45 \mathrm{~m}$ ), and in the atmosphere at $0.85 \mathrm{~m}$ from the ice. (a) Profiles over slush. (b) Profiles over solid ice (note the different scale of the $y$ axis). 


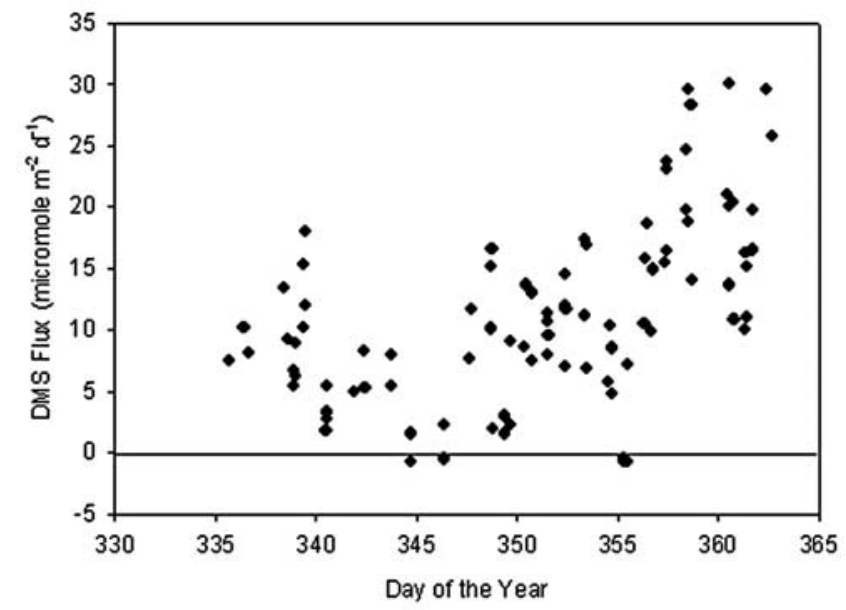

Figure 3. DMS fluxes ( $\mu$ mol DMS $\mathrm{m}^{-2} \mathrm{~d}^{-1}$ ) over the multi-year ice in the western Weddell Sea as measured by relaxed eddy accumulation in December 2004.

the flux of DMS could possibly be even higher if its production and release continue to increase as summer progresses.

[20] Acknowledgments. This work was financially supported by the Marie Curie Training Site Fellowship (contract HPMF-CT-2002-01865), by NERC (award NER/B/S/2003/00844) and by the U.S. National Science Foundation (OCE-0327601, and OCE-0425166). We would also like to thank the WHOI Ocean Life Institute. The authors would like to express their deepest thanks and appreciation to the crew of the R.V. Polarstern for all their efforts in helping us throughout ANT XXII/2. Thanks also to the chief scientist M. Spindler and to the AWI for making the cruise possible.

\section{References}

Albert, M. R., and E. F. Shultz (2002), Snow and firn properties and airsnow transport processes at Summit, Greenland, Atmos. Environ., 36, $2789-2797$.

Arrigo, K. R., Jr. (1998), Physical forcing of phytoplankton dynamics in the southwestern Ross Sea, J. Geophys. Res., 103(C1), 1007-1021.

Charlson, R. J., J. E. Lovelock, M. O. Andreae, and S. G. Warren (1987), Oceanic phytoplankton, atmospheric sulphur, cloud albedo and climate, Nature, 326, 655-661.

Curran, M. A. J., and G. B. Jones (2000), Dimethylsulphide in the Southern Ocean: Seasonality and flux, J. Geophys. Res., 105(D16), 20,45120,461 .

Fairall, C. W., J. E. Hare, J. B. Edson, and W. R. McGillis (2000), Parameterization and micrometeorological measurement of air-sea gas transfer, Boundary Layer Meteorol., 96, 63-105.

Gabric, A. J., R. Cropp, A. Hirst, and H. Marchant (2003), The sensitivity of dimethylsulphide production to simulated climate change in the eastern Antarctic Southern Ocean, Tellus, Ser. B, 55, 966-981.

Gabric, A. J., R. Simó, R. A. Cropp, A. C. Hirst, and J. Dachs (2004), Modeling estimates of the global emission of dimethylsulfide under en- hanced greenhouse conditions, Global Biogeochem. Cycles, 18, GB2014, doi:10.1029/2003GB002183.

Gabric, A. J., J. M. Shephard, J. M. Knight, G. Jones, and A. J. Trevena (2005), Correlations between the satellite-derived seasonal cycles of phytoplankton biomass and aerosol optical depth in the Southern Ocean: Evidence for the influence of sea ice, Global Biogeochem. Cycles, 19, GB4018, doi:10.1029/2005GB002546.

Gloersen, P., W. J. Campbell, D. J. Cavalieri, J. C. Comiso, C. L. Parkinson, and H. J. Zwally (1992), Arctic and Antarctic sea ice, 1978-1987: Satellite passive-microwave observations and analysis, NASA Spec. Publ., $S P-511,290 \mathrm{pp}$

Gondwe, M., M. Krol, W. Gieskes, W. Klaassen, and H. de Baar (2003), The contribution of ocean-leaving DMS to the global atmospheric burdens of DMS, MSA, $\mathrm{SO}_{2}$, and $\mathrm{NSS} \mathrm{SO}_{4}^{-}$, Global Biogeochem. Cycles, 17(2), 1056, doi:10.1029/2002GB001937.

Hintsa, E. J., J. W. H. Dacey, W. R. McGillis, J. B. Edson, C. J. Zappa, and H. J. Zemmelink (2004), Sea-to-air fluxes from measurements of the atmospheric gradient of dimethylsulfide and comparison with simultaneous relaxed eddy accumulation measurements, J. Geophys. Res., 109, C01026, doi:10.1029/2002JC001617.

Kettle, A., and M. O. Andreae (2000), Flux of dimethylsulfide from the oceans: A comparison of updated data sets and flux models, J. Geophys. Res., 105(D22), 26,793-26,808.

Semiletov, I., A. Makshtas, S.-I. Akasofu, and E. L. Andreas (2004), Atmospheric $\mathrm{CO}_{2}$ balance: The role of Arctic sea ice, Geophys. Res. Lett., 31, L05121, doi:10.1029/2003GL017996.

Shaw, G. E. (1985), Bio-controlled thermostatis involving the sulfur cycle, Clim. Change, 5, 297-303.

Takagi, K., M. Nomura, D. Ashiya, H. Takahashi, K. Sasa, Y. Fujinuma, H. Shibata, Y. Akibayashi, and T. Koike (2005), Dynamic carbon dioxide exchange through snowpack by wind-driven mass transfer in a coniferbroadleaf mixed forest in northernmost Japan, Global Biogeochem. Cycles, 19, GB2012, doi:10.1029/2004GB002272.

Trevena, A. J., and G. B. Jones (2006), Dimethylsulphide and dimethylsulphoniopropionate in Antarctic sea ice and their release during sea ice melting, Mar. Chem., 98, 210-222.

Trevena, A. J., G. B. Jones, S. W. Wright, and R. L. van den Enden (2000), Profiles of DMSP, algal pigments, nutrients and salinity in pack ice from eastern Antarctica, J. Sea Res., 43, 265-273.

Trevena, A. J., G. B. Jones, S. W. Wright, and R. L. van den Enden (2003), Profiles of dimethylsulphoniopropionate (DMSP), algal pigments, nutrients, and salinity in the fast ice of Prydz Bay, Antarctica, J. Geophys. Res., 108(C5), 3145, doi:10.1029/2002JC001369.

Zemmelink, H. J., W. W. C. Gieskes, W. Klaassen, W. J. Beukema, H. W. de Groot, H. J. W. de Baar, E. J. Hintsa, W. R. McGillis, and J. W. H. Dacey (2004), Relaxed eddy accumulation measurements of the sea-toair transfer of dimethylsulfide over the northeastern Pacific, J. Geophys. Res., 109, C01025, doi:10.1029/2002JC001616.

Zemmelink, H. J., L. Houghton, J. W. H. Dacey, A. P. Worby, and P. S. Liss (2005), Emission of dimethylsulfide from Weddell Sea leads, Geophys. Res. Lett., 32, L23610, doi:10.1029/2005GL024242.

Zemmelink, H. J., B. Delille, J. L. Tison, E. J. Hintsa, L. Houghton, and J. W. H. Dacey (2006), $\mathrm{CO}_{2}$ deposition over the multi-year ice of the western Weddell Sea, Geophys. Res. Lett., 33, L13606, doi:10.1029/ 2006GL026320.

J. W. H. Dacey, E. J. Hintsa, and L. Houghton, Woods Hole Oceanographic Institution, Woods Hole, MA 02543, USA.

P. S. Liss, School of Environmental Sciences, University of East Anglia, Norwich NR4 7TJ, UK.

H. J. Zemmelink, Royal Netherlands Institute for Sea Research, NL-1790 AB Den Burg, Netherlands. (zemmelink@nioz.nl) 